Orbis Tertius, vol. XXII, $n^{\circ}$ 26, e054, diciembre 2017. ISSN 1851-7811

Universidad Nacional de La Plata

Facultad de Humanidades y Ciencias de la Educación

Centro de Estudios de Teoría y Crítica Literaria

\title{
Ducasse y Onetti se encuentran en Rocambole
}

\author{
Alma Bolón * \\ * Universidad de la República, Uruguay.
}

\section{PALABRAS CLAVE}

Juan Carlos Onetti

Isidore Ducasse

Lautréamont

\section{KEYWORDS}

Juan Carlos Onetti

Isidore Ducasse

Lautréamont

\section{RESUMEN} contar.

\section{ABSTRACT}

Muy notoria en abundantes lugares, la presencia de la literatura francesa en la obra de Juan Carlos Onetti incluye pocas referencias explícitas a los Cantos de Maldoror. Para rastrear las huellas de Isidore Ducasse en la obra de Juan Carlos Onetti, conviene pegar un rodeo, que conducirá hasta Rocambole, Silvio Astier y Fantomas. De este modo, es posible percibir un aire de familia que se expande y alcanza a Lautréamont, Onetti, Arlt, Ponson du Terrail y Pierre Souvestre \& Marcel Allain, envolviendo no solo temas y personajes sino también y fundamentalmente una particular relación entre el saber y el

Often very noticeable elsewhere, the presence of French literature in Juan Carlos Onetti's works includes few explicit references to Les Chants de Maldoror. In order to trace the influence of Isidore Ducasse in Onetti's texts, a journey around the characters of Rocambole, Silvio Astier and Fantomas will prove fruitful. Thus, it will be possible to perceive an expanding resemblance that links Lautréamont, Onetti, Arlt, Ponson du Terrail and Pierre Souvestre \& Marcel Allain, involving themes, characters, and also most significantly a peculiar relation between knowing and telling.

Cita sugerida: Bolón, A. (2017). Ducasse y Onetti se encuentran en Rocambole. Orbis Tertius, $22(26)$, e054. https://doi.org/10.24215/18517811e054 


\section{Una presencia exacta}

Muy notoria en abundantes lugares, la presencia de la literatura francesa en la obra de Juan Carlos Onetti (Bolón 2014) parece haber incluido muy pocas referencias explícitas a los Cantos de Maldoror. Entre éstas aparece aludida en son de chanzas la célebre figura ducassiana sobre el encuentro entre una máquina de coser y un paraguas: "para la enorme mayoría de los varones una "nínfula" tiene tanto que ver con el amor como una máquina de coser, coincida o no con un paraguas”, escribe Onetti (1976:151). En estas líneas, se reconocen de inmediato los términos de una comparación que, en cierta forma, se desprendieron de los Cantos de Maldoror y se pusieron a circular por cuenta propia, por lo que son pasibles de surgir en los contextos más variados, en general ilustrando un encuentro extraño, sin más. (Por ejemplo, Parapluie y Machine à coudre llegaron a ser los nombres de los dos personajes de “Vous m'entendez”, un texto dramático escrito por Philippe Soupault y André Breton a comienzos de los años 20; Michel Foucault, en el inicio de Les mots et les choses, recuerda esta comparación ducassiana, también evocada por Julio Cortázar en el comienzo de Rayuela.)

Por esta disposición a presentarse en variados contextos, es llamativa la exacta oportunidad de su evocación por Onetti -justamente, en una nota sobre Lolita de Nabokov-, dado que la comparación de Ducasse ilustra la rareza de la belleza de Mervyn, personaje de quien, dos líneas antes el narrador ha dado su edad precisa: “dieciséis años y cuatro meses". A todas luces, en Onetti, el encuentro fortuito del paraguas y de la máquina de coser no es evocado para ilustrar solamente una rareza, sino que, en el contexto de la nota sobre Lolita, su evocación también actualiza las jóvenes edades de Mervyn, de Lolita y de las Virginia Cras y otras nínfulas onettianas.

Esta exacta pero tan discreta presencia de Ducasse en Onetti, que a lo largo de sesenta años de escritura ha nombrado, citado, incorporado y comentado a decenas de autores franceses, sin duda puede vincularse con la poca atención concedida por Onetti a André Breton y al surrealismo, confinado a anotaciones caseras y juegos de colegial, como si la intimidad de la escritura privada fuera el lugar de ajustar cuentas con esos oficiantes inverosímiles que son los surrealistas. $\underline{1}^{1}$

\section{Ducasse, Onetti: un aire de familia}

No obstante, esta forma onettiana de parquedad con respecto a la obra ducassiana no impide que se trasluzca un insistente aire de familia, por el que ambos autores comparten una atención incansada a los asuntos del bien y del mal y una decidida propensión a no dejarse arrullar por la esperanza. Ducasse, sin vueltas, hace de Maldoror el vencedor de ésta, y la materia misma de la desesperanza: “Ainsi donc, Maldoror, tu as vaincu l'Espérance! Désormais, le désespoir se nourrira de ta substance la plus pure!” (2001:209). Formando parte del mismo aire de familia, se percibe su compartido encono contra la institución familiar; Ducasse lo declara en términos, nuevamente, casi bélicos: “J’ai fait un pacte avec la prostitution afin de semer le désordre dans les familles” (2001:91).

Como plato fuerte servido por este pacto hecho con la prostitución, se encuentra a fines del Canto Tercero de Maldoror el episodio en que un cabello caído de la cabeza de Dios, y abandonado por éste, narra las divinas actuaciones en un prostíbulo, actuaciones propias de una divinidad más satánica que celestial. ¿Puede haber mayor pacto con la prostitución que el pacto que tiene a Dios aposentado en el burdel?

Desde El Pozo, con Ester, pobre prostituta con balzaciano nombre de cortesana esplendorosa, Onetti tuvo presente la prostitución, como nombre genérico de variadas figuras del amor y del desamor. Piénsese nomás en Juntacadáveres, o en La vida breve, novela que simultáneamente rezuma francidad, y que presenta a Mami, francesa ex prostituta, y a Enriqueta, de elocuente apodo: la Queca. Se recordará que en La vida breve la historia se abre in medias res con una exclamación -”Mundo loco"- que la Queca profiere, dice el narrador, como "remedando, como si lo tradujese". Se recordará también que José Emilio Pacheco ha contado que Onetti, al regalarle un ejemplar de La vida breve tachó la frase inicial y anotó encima el íncipit que debería haber sido pero que, en 1950, no habría obtenido el vistobueno de la editorial Sudamericana: "Burdel de Dios" (Verani 2009:67). $\underline{2}$ Esta expresión es un calco en español de otra en francés-”bordel de Dieu”- completamente lexicalizada en ese 
idioma, de valor exclamativo y con significados que van desde la expresión del disgusto hasta la sencilla sorpresa, pero que siempre suspenden la idea de un burdel que es aposento de Dios. El calco en español deslexicaliza pues la bastante inofensiva expresión francesa, haciendo que se oiga no ya una vaga exclamación, sino un preciso "burdel de Dios".

¿Es lícito ver en el descartado íncipit de La vida breve y en el personaje de la Queca reminiscencias no solo del pacto ducassiano con la prostitución para sembrar el desorden en las familias, sino más precisamente reminiscencias del episodio, estructural y textualmente central en los Cantos de Maldoror, del burdel de Dios?

Esta percepción resulta lícita gracias, sobre todo, a que nuevos miembros se agregan a la familia, intensificando colateralmente los rasgos compartidos por Ducasse y por Onetti.

\section{Una familia lectora extendida: Onetti, Arlt, Rocambole, Fantomas}

Si escasea la presencia explícita de Ducasse en Onetti, no sucede lo mismo con los frecuentes y admirados comentarios de Onetti con respecto a Arlt, que se suman al vínculo personal, intelectual y editorial que los unió. Por su parte, Roberto Arlt no escatimó homenajes a Rocambole, el héroe antihéroe que inventa Ponson du Terrail en esa segunda edad del folletín que, a grandes rasgos, corresponde con el Segundo Imperio (Meyer 2005). En la breve extensión de El juguete rabioso, Rocambole vuelve más de una vez en boca de su protagonista, que de entrada declara su familiaridad y su admiración por el bandido: "Yo ya había leído los cuarenta y tantos tomos que el vizconde de Ponson du Terrail escribiera acerca del hijo adoptivo de mamá Fipart, el admirable Rocambole, y aspiraba a ser un bandido de la alta escuela" (Arlt 1982:13). Avanzada la historia, el personaje Rocambole vuelve en boca del protagonista, ahora erigido en modelo de vida y equiparado al poeta Baudelaire: “ ¡Oh ironía!, y yo que era el que había soñado en ser un bandido grande como Rocambole y un poeta genial como Baudelaire!” (Arlt 1982:45). Más adelante, en una tercera aparición, se muestra cómo, efectivamente, Rocambole ya es modelo de conducta para el protagonista, al punto que su "catadura” bandidesca se le impone como un súper yo insobornable: "Y en aquel instante, antes de hablar, pensé en los héroes de mis lecturas predilectas y la catadura de Rocambole, del Rocambole con gorra de visera de hule y sonrisa heroica” (Arlt 1982:68).

Se conoce el juicio que suscitó en Onetti la presencia de Rocambole en Arlt: "Supe que leyó Dostoievski en miserables ediciones argentinas de su época. Humillados y ofendidos, sin duda alguna. Después descubrió Rocambole y creyó. Era, literalmente, un asombroso semianalfabeto. Nunca plagió a nadie; robó sin darse cuenta” (1976:135). Dejando de lado el debate en que Onetti se sumerge como sin querer pero braceando agua para su molino -su siemprelista reivindicación de la estirpe, que él reclama integrar, de escritores "antiintelectuales", escritores casi como por inadvertencia, y la siempre viva reivindicación de la distinción entre literaturas "altas” y “bajas"-, vale la pena atender el destaque que Onetti hace de Rocambole en Arlt. Algunos años más tarde, Onetti establecerá un mudo paralelismo con esa destacada pareja que lo precedió, al contar sobre el lugar preponderante que tuvieron las aventuras de Fantomas en su formación de lector y de escritor. Como corresponde a la índole aventurera de esas lecturas, para alcanzarlas, Onetti debía caminar más de diez kilómetros diarios, hasta llegar a la casa de un tío que poseía la obra y se la suministraba tomo a tomo. "Por culpa de Fantomas" se llamó el texto en que Onetti hizo el relato de esos comienzos, en los que también hizo figurar las lecturas de Jules Verne que hacía en la biblioteca del Museo Pedagógico de Montevideo, aunque aquella lectura exhaustiva que Onetti rememoraba haber hecho -"y me tragué todas las obras de Jules Verne”- no hubiera bastado como para que Verne, elevándose al grado de "culpable", se izara hasta el título en donde solo Fantomas acaparó toda el mérito de la culpa (Onetti 2013:17).

Testimonio veraz, o mitológico relato de los orígenes, o inextricable combinatoria de ambos, lo cierto es que Onetti, poco después de haber señalado el continental lazo entre Arlt y Rocambole -Arlt "descubrió Rocambole"-, coloca en sus propios principios un personaje sucesor de Rocambole, como para subrayar que él pertenece al mismo linaje de Arlt.

Sin duda, podría entenderse esto como una sencilla coincidencia, o como una coquetería de un autor exquisito y 
provocador, que busca épater con sus orígenes bajofonderos. Y sin embargo, una verdad sólida, inscripta en la propia escritura de Onetti se arraiga en esa narración sobre los orígenes. Antes de explayarnos sobre esto, una vuelta a Ducasse.

\section{La familia empieza a enmascararse: Isidore Ducasse, Latréaumont, Lautréamont, Rocambole}

Entre algunos estudiosos y admiradores de los Cantos de Maldoror, ha persistido el gusto por hacer sonar en el pseudónimo "Lautréamont" el sintagma "l'autre à Mont”, perfectamente homófono y provisto de significado llanamente montevideano, si admitimos el apócope. Entre otros estudiosos, hoy se ha impuesto una explicación diferente, no necesariamente incompatible con la primera, pero que sí vincula el pseudónimo elegido por Ducasse con el título de una exitosa novela de Eugène Sue, Latréaumont, obra previa a los Misterios de París, publicada por primera vez en 1838 y objeto de muchas reediciones y adaptaciones teatrales. El éxito la había traído hasta Montevideo, puesto que Latréaumont figura en el catálogo de 1862 de la Librería Extranjera de Francisco Rival, único título de Sue, tal como lo reproducía el Observateur Français (Lefrère 1998:480). Concomitantemente, los partidarios del origen 'Latréaumont’ de 'Lautréamont’ señalan que en las épocas en que Isidore Ducasse iba por la oficina de su editor Albert Lacroix, éste había reeditado Latréaumont, por lo que el pseudónimo "comte de Lautréamont" puede haber sido inspirado a Ducasse por el nombre de la novela de Eugène Sue, o puede haber sido iniciativa del propio editor Lacroix, con errata incluida o con pequeña variación deliberada. $\underline{3}$ Lo cierto es que, a través del pseudónimo, es posible establecer un primer lazo entre Ducasse y el universo del primer folletín, el que encarna Eugène Sue en los años 30 y 40 del siglo XIX.

Un segundo vínculo completamente explícito, ahora con el folletín del Segundo Imperio, se plasma en las referencias que realiza Ducasse a Rocambole, único personaje en ser distinguido con dos menciones en las breves obras completas. Una primera mención aparece en el Canto Sexto de Maldoror -”ce poètique Rocambole”, dice el narrador-; y otra en Poésie I, en que se estipula que “chanter Adamastor, Jocelyn, Rocambole, c’est puéril”.

Recapitulando. No es difícil rastrear un conjunto de citas y menciones que enlazan a Isidore Ducasse con dos grandes folletinistas del siglo XIX, Eugène Sue y Ponson du Terrail, que a su vez ocupan lugares privilegiados en los rioplatenses Arlt y Onetti. Así visto, Onetti también se encuentra con Ducasse en las citas y menciones de Rocambole. No obstante, el aire de familia impregna algo más fundamental, puesto que embebe la propia escritura que desarrollan estos autores, con sus procedimientos y con sus preocupaciones.

\section{Avanzar enmascarado: Maldoror, Rocambole, Fantomas, Brausen}

Como se sostuvo al comienzo de estas páginas, es notoria la sustancia antiheroica de los héroes de Ducasse y de Onetti, portadores de una desesperanza radical. El héroe de Ponson du Terrail no se queda en zaga, porque si la traición, la impostura y la estafa fundan la época a la que después nacerá Rocambole, éste, hijo de guillotinado y carne de cadalso, rápidamente hará honor a su tiempo, haciendo de la infamia un hábito insoslayable. Pero no será en esta dimensión en la que nos detendremos, sino en los varios modos de enmascaramiento que van haciendo la historia rocambolesca, ducassiana y onettiana, más particularmente, en su avanzar enmascarado.

De cierta manera, el principio narrativo de Ponson du Terrail, reconocible como lo "rocambolesco", puede ser entendido como un torrente de peripecias propiciadas por el incesante enmascaramiento de los personajes, por su continuo disfraz y usurpación de identidades, que los multiplica en un incansable accionar. Piénsese nomás que el gran villano Andréa Felipone, medio hermano del galante Armand de Kergaz, se confunde a lo largo de toda la historia con el impostado Sir Williams; o que el propio Rocambole, Joseph Fipart por adoptado apellido de su madre adoptiva, también responderá, entre otras muchas más, a las identidades de vizconde de Cambolh, marqués Albert de Chamery y mayor Avatar. De hecho, podría decirse que "Rocambole" es apodo, sobrenombre sin nombre, sobrenombre de lo que no tiene ni nunca tuvo nombre propio.

En ese sentido, es interesante cotejar la escena del duelo entre el muy leal Bastien y el mentido Sir Williams (en quien, con razón, Bastien ha creído reconocer al pérfido Andréa Felipone) tal como la escribe Ponson du Terrail y 
tal como la escenifica Jean-Pierre Decourt para una serie televisiva, en 1964. En su magnífica realización, Decourt pone en boca de Sir Williams una réplica ausente en el texto de Ponson du Terrail, y sin embargo imbuida de rocambolismo: “J'approche mon ennemi à visage découvert tout en gardant le meilleur des masques” (Decourt 1964). Cien años más tarde, y durante los subversivos 60, Decourt puede explicitar la dimensión filosófica, en cuanto a identidades e imposturas, que cultivaba el rocambolismo. (¿Acaso este folletín era tan ajeno a un Segundo Imperio que era el travestimiento del Imperio, acaso Louis Napoléon -el Pequeño, según Victor Hugono era la versión farsesca de Napoléon Bonaparte, según lo sostenía Marx?). $\stackrel{4}{4}$

Este juego de disfraces y de usurpaciones atrae explícitamente a Ducasse que, concluyendo los Cantos, en el sexto precisamente, dice de Maldoror: "Il avait une faculté spéciale pour prendre des formes méconnaissables aux yeux exercés. Déguisements supérieurs, si je parle en artiste!”. Esta caracterización antecede en pocas líneas la comparación explícita entre Rocambole y Maldoror:

Aujourd'hui il [Maldoror] est à Madrid ; demain il sera à Saint-Petersbourg; hier il se trouvait à Pékin. Mais, affirmer exactament l'endroit actuel que remplissent de terreur les exploits de ce poétique Rocambole est un travail au-dessus des forces possibles de mon épaisse ratiocination (2001:311).

Si esta explícita declaración de identidad entre Maldoror y “ese poético Rocambole” llega a finales de los Cantos, desde sus inicios, desde el título mismo, se percibe una afinidad menos patente, tal vez menos temática y más arraigada en los modos de enunciar, como si Ducasse la hubiera absorbido y entramado.

Véase nomás la equivocidad del título Cantos de Maldoror que, con manifiesta simplicidad, no elucida si se tratará de cantos sobre Maldoror, o de cantos entonados por Maldoror, o de cantos sobre Maldoror entonados por Maldoror. A medida de que el texto va avanzando, la identificación de quién canta se va intrincando, y con razón, puesto que, de entrada, el narrador avisó que suele calzar algo bastante similar a un antifaz:

Et quand je rôde autour des habitations des hommes, pendant les nuits orageuses, les yeux ardents, les cheveux flagellés par le vent des tempêtes, isolé comme une pierre au milieu du chemin, je couvre ma face flétrie, avec un morceau de velours, noir comme la suit qui remplit l'intérieur des cheminées: il ne faut pas que les yeux soient témoins de la laideur que l’Être suprême, avec un sourire de haine puissante, a mise sur moi (2001:95-96).

Dos estrofas después, el narrador hablará de su rostro de hiena (“sur mon visage d'hyène”) y en el íncipit del Canto Cuarto, se declara: "C'est un homme ou une pierre ou un arbre qui va commencer le quatrième chant"; mientras que en el Canto Quinto se advierte en retrospectivo contrapunto con un Rimbaud todavía en ciernes: "Si j'existe, je ne suis pas un autre. Je n’admets pas en moi cette équivoque pluralité. Je veux résider seul dans mon intime raisonnement”. Ni qué decir, claro está, sobre la identificación de la voz narrativa en tanto que "poète” y “Montevidéen”.

La equivocidad clavada en el título por el heredado genitivo latino no se disuelve pues en el cuerpo del texto que, por el contrario, desorienta al lector, expuesto a una voz que suena en la historia contada, pero que ese lector no logra identificar en ningún caso. Algunas huellas de esta incomodidad se ven en notas al pie que ofrecen los editores, por ejemplo, cuando se sienten obligados a precisar en el pie de página: “'Je’ s'exprime ici en tant qu'auteur du premier chant” (2001:127). Semejantemente, ante un “Éloigne-toi, Maldoror, de ce foyer paisible; ta place n’est pas ici”, el editor se sintió en la obligación de explicar el juego pronominal anulando el equívoco que desorienta, y anotó al pie de página : "Il s’agit bien entendu de Maldoror que se parle à lui-même” (2001:109). Por cierto, canto a canto y estrofa a estrofa, estos juegos pronominales confunden la identificación de la voz narrativa, cosa que se conjuga perfectamente con la índole paródica, de pastiche o mosaico discursivo que constituye a los Cantos y que instala una pluralidad de voces, inevitablemente negadas, y, sobre todo, cosa que forma parte del juego, por la declaración de unidad unificada, antes mencionada, "Si j'existe, je ne suis pas un autre. Je n’admets pas en moi cette équivoque pluralité” (2001:279). 
Puede pensarse este juego con la pluralidad de la voz narrativa que practica Ducasse como una elaboración más sofisticada de los rocambolescos travestimientos de Ponson du Terrail, como si el disfraz y la impostura ganaran refinamiento al incumbir no solo a los personajes sino también al mismísimo narrador.

Por cierto, esto no podía sino encantar a Onetti, que ha practicado una escritura del equívoco y del travestimiento en más de una oportunidad y en diferentes planos. ¿Acaso Rita, protagonista de Para una tumba sin nombre que mendiga acompañada de su chivo Gerónimo en la explanada de la estación Constitución, en Buenos Aires, no es el travestimiento desesperanzado de Esmeralda que baila con su cabrita Djali en la explanada de la catedral NotreDame? ¿Acaso la Ester de El pozo, prostituta que soporta mal los arrestos poéticos de Eladio Linacero, no es otro travestimiento desesperanzado de la cortesana Esther Gobseck esplendorosamente enamorada del poeta Lucien de Rubempré? ¿Acaso la protagonista de "El álbum”, Carmen Méndez (admitiendo que ese fuera su nombre) no imposta, ante Jorge Malabia, un pasado que solo pudo existir en el presente de su invención? ¿Acaso Baldi, abogado colmado de barrial satisfacción, no se traviste en aventurero sórdido antes los ojos de una mujer encontrada en la calle? ¿Acaso el título "Jacob y el otro”, al silenciar el nombre del "otro”, correlativamente no echa oscuridad sobre los individuos pasibles de ser nombrados “Jacob”? $\underline{6}$

De igual modo, es lícito comparar la desazón que experimenta el lector de los Cantos de Maldoror ante una voz narrativa que avanza enmascarada con la experimentada por los lectores de Onetti, por ejemplo, en La vida breve, o en "Esbjerg, en la costa" o "Para una tumba sin nombre". Puede conjeturarse que la elección de Fantomas, por parte de Onetti, como obra en los orígenes de la suya propia, no solo actualiza la pareja 'Arlt/Rocambole', sino que la explicita, dado que las representaciones de Fantomas -en las tapas de los libros y en los affiches de sus películas- nunca omiten el antifaz.

\section{Avanzar inventando: Maldoror, Rocambole, Brausen}

Cabe conjeturar que la principal afinidad entre Ponson du Terrail, Ducasse y Onetti tiene que ver con la manera en la que jugaron a mostrar el revés de la trama, exhibiendo no solo el invento sino el propio proceso de invención, con su extraordinaria fuerza performativa. Porque, como es sabido, buena parte de la novelística que se inicia en el siglo XVIII y se prosigue en el XIX parte de la base de que la materia contada antecede y es independiente del acto de contarla. Ya sea que se trate de aventuras vividas por quien luego las contará, de relatos oídos de boca de sus protagonistas o de terceras personas, de manuscritos encontrados en arcones o llegados azarosamente a manos del narrador, sea como se sea, en todos los casos, se dan por descontadas la anterioridad y la autonomía de la historia que se narra con respecto al acto de narrarla. Naturalmente, esto es pura ilusión retrospectiva, creada por el propio discurso literario, ya que suele suceder que la narración de la historia coincide con su invención, por lo que no hay materia previa inventada, sino materia en invención, inclusive en las parodias o en las reescrituras.

Muchos textos de Onetti, en particular La vida breve, pero no solo, pretenden ilustrar ese proceso de construcción y, denunciando la inexistencia de una materia previa que pudiera hacer de "pasado" de la escritura, insisten en la contemporaneidad del invento y de la invención, en el pasado como pura fabricación del presente, en la condición supremamente hacedora del escritor.

Por esto, cabe conjeturar el interés con que Onetti habrá leído los pasajes rocambolescos en que el disfraz y la impostura de los personajes se textualiza como el acto del escritor que, liberado de cualquier obligación con respecto a un referente previo, soberanamente hace nacer a su personaje en el momento de escribirlo, es decir, ante los ojos del lector, espectador del parto. Véase por ejemplo el diálogo siguiente entre un Sir Williams que le pregunta a Rocambole si estaba muy apegado a su título de vizconde sueco (vicomte de Cambolh), ya que se propone convertirlo en marqués brasileño:

-Dis-donc, fit gravement sir Williams, tenais-tu beaucoup à ton titre de vicomte suédois ?

-Mais dame! J'étais assez bien posé dans le monde.

-Je te crée marquis brésilien.

-Peste! 
-A l'avenir tu t'appelleras don Inigo, marquis de los Montes ; tu seras le descendant d'une vieille race espagnole, établie au Brésil depuis un siècle. Tes ancêtres ruinés au service de l'Espagne, ont fait une fortune fabuleuse au Brésil en défrichant de vastes solitudes, et tu dépenses follement à Paris les revenus de tes nombreux troupeaux de buffles, de moutons et de chevaux. Tu es un gentilhomme pasteur" (2009:356).

El acto de imposición a Rocambole de una nueva identidad sin duda se engarza en la trama de este folletín, en esa larga cadena de imposturas que es la vida de Sir Williams y de Rocambole, y relanza así nuevas posibilidades de peripecias. Pero sobre todo, esta escena replica y desnuda dentro de la ficción, por el poder que Sir Williams tiene sobre su protegido Rocambole, lo que parece suceder fuera de ella, por el poder del novelista sobre sus personajes. De hecho, nada importa a Sir Williams la poca disposición de Rocambole para abandonar su carácter de vizconde sueco, y el travestimiento en marqués brasileño se impone en el mismo acto de habla, esencialmente performativo, en que se impone un pasado heroico, un linaje noble, una dinastía acaudalada y un futuro en consecuencia.

Algo semejante aparece en el inicio del último Canto, en ese sexto canto que no solo pierde su estructura en estrofas sino que el narrador explícitamente considera "un petit roman", al tiempo que declara aprestarse a "fabricar[lo]":

Prétendriez-vous donc que, parce que j’aurais insulté en me jouant, l’homme, le Créateur et moi-même, dans mes explicables hyperboles, ma mission fût complète? Non : la partie la plus importante de mon travail n'en subsiste pas moins, comme tâche qui reste à faire. Désormais les ficelles du roman remueront les trois personnages nommés plus haut: il leur sera communiqué une puissance moins abstraite. La vitalité se répandra magnifiquement dans le torrent de leur appareil circulatoire [...] Aujourd'hui, je vais fabriquer un petit roman de trente pages, et je devais à moi-même, avant de boucler ma valise et me mettre en marche pour les contrées de l'imagination, d'avertir les sincères amateurs de la littérature, par l'ébauche rapide d'une généralisation claire et précise, du but que j’avais résolu de poursuivre (2001:307309).

Aunque sin participar estrictamente de la trama general, como sí lo hace el fragmento antes citado en que Sir Williams traviste a Rocambole de marqués brasileño, en este pasaje de los Cantos, el narrador declara los inminentes pasos que dará, en tanto que hacedor de personajes a los que los hilos de la novela -las reglas del artedarán movimiento e insuflarán vitalidad.

Ducasse y Onetti no comparten solamente una cuidadosa atención a la desesperanza, una galería de antihéroes y de infamias, de imposturas y de estafas. Comparten también una propensión a trasladar el travestimiento y el enmascaramiento al plano de la narración misma, lo que redunda en una complejidad que, abandonando el terreno de lo llanamente moral, pone en juego la posibilidad de la verdad en tanto que correspondencia entre un decir y un estado del mundo, así como del acceso a ésta a través de la ficción.

\section{NOTAS}

1 Entre los papeles manuscritos de Onetti donados por Dolly Muhr a la Biblioteca Nacional en Montevideo, figura una agenda correspondiente al año 1991 con una anotación autógrafa que dice «Definición del Diccionario surrealista bendecida por André Breton», seguida de «Y ano joder más Juan Ucho».

$\underline{2}$ Sin atender los vínculos con Ducasse, éste y otros calcos en Bolón (2014).

$\underline{3}$ Tanto Jean-Jacques Lefrère (1998) como Jean-Luc Steinmetz (2009), especialistas principales en Isidore Ducasse, admiten esta explicación para el pseudónimo elegido. Por mi parte, agregaré que la trama de Latréaumont puede haber interesado a Ducasse, ya que se narra un complot para crear una república en una ciudad 
normanda, con derrocamiento de Louis XIV incluido. También agrego que fragmentos de Latréaumont habían sido publicados en 1838 por la Revue des Deux Mondes, periódico que formaba parte de las lecturas de François Ducasse, padre de Isidore, tal como lo señala el trabajo pionero de los hermanos Guillot (2009:20).

4 Para un análisis detallado ver Meyer (2005).

$\underline{5}$ Ambas notas figuran en la edición de bolsillo de Les Chants de Maldoror, y están ausentes de la edición de la Pléiade.

6 Para un análisis detallado de estos ejemplos ver Bolón (2014).

\section{BIBLIOGRAFÍA}

Arlt, Roberto (1982) [1926]. El juguete rabioso, Montevideo, Lectores de Banda Oriental.

Bolón, Alma (2014). Onetti francés. Estudios de lengua, literatura y civilización francesa en Onetti, Montevideo, Universidad de la República/CSIC.

Decourt, Jean-Pierre (1964). L'héritage mystérieux, chap. XXIX, "Le duel”; https://www.youtube.com/watch? $\underline{\mathrm{v}=\mathrm{HVe} \text { q8-kElU }}$

Guillot Muñoz, Gervasio, en colab. con Álvaro Guillot Muñoz (2009) [1935]. "La leyenda de Lautréamont”, Escritos, Montevideo, Biblioteca Artigas, Colección de clásicos uruguayos, vol.180, edic. de Pablo Rocca.

Lautréamont (2001) [1869]. Les Chants de Maldoror et autres textes, París, Les Classiques de Poche.

Lautréamont (2009) [1869]. Euvres complètes, Paris, Gallimard, coll.”Bibliothèque de la Pléiade”.

Lefrère, Jean-Jacques (1998). Isidore Ducasse. Auteur des Chants de Maldoror, par le comte de Lautréamont, París, Fayard.

Meyer, Marlyse (2005) [1996]. Folhetim. Uma história, San Pablo, Companhia das Letras.

Onetti, Juan Carlos (1975) [1959]. “Otra vez 'Lolita”,,Requiem por Faulkner y otros artículos. Montevideo, Arca/Calicanto, edic. de Jorge Ruffinelli.

Onetti, Juan Carlos (1975) [1971]. “Roberto Arlt”, Requiem por Faulkner y otros artículos. Montevideo, Arca/Calicanto, edic. de Jorge Ruffinelli.

Onetti, Juan Carlos (2013) [1974]. “Por culpa de Fantomas”, Miscelánea, Barcelona, Galaxia Gutenberg.

Ponson du Terrail, Pierre-Alexis (2009) [1858]. Rocambole II, Le club des Valets-de-Cour, https://www.ebooksgratuits.com/pdf/ponson du terrail rocambole club des valets de coeur 2.pdf

Steinmetz, Jean-Luc (2001). Préface, notes et commentaires de Les Chants de Maldoror et autres textes, París, Les Classiques de Poche.

Steinmetz, Jean-Luc (2009). Préface, chronologie, notes, Euvres complètes, Lautréamont, Paris, Gallimard, coll.”Bibliothèque de la Pléiade”.

Verani, Hugo J. (2009) [1981] Onetti: el ritual de la impostura. Montevideo, Biblioteca Nacional-Trilce. 